\section{The Italian Earthquake of July 23.}

YINCE Jan. 13, 1915, when Avezzano and other towns in central Italy were ruined, there has been no earthquake in the peninsula so destructivo as that which visited the provinces of the Basilicata and Campania shortly after 1 A.M. (0 A.M. Greenwich mean time) on July 23 . The latest estimate of the number of persons killed is 1883, while the buildings of 34 communes are said to have been seriously damaged. The epicentre, which seems to be close to the town of Lacedonia, lies about 65 miles slightly north of east from Naples.

The aroa of slight damage, as at present known, is bounded by a curve that is roughly in the form of an ellipse directed west-north-west, 39 miles long, 16 miles wide, and containing about 490 square miles. The places that have suffered most are Villanova, Aquilonia, and Lacedonia, lying within a district about 19 miles long and 90 square miles in area, in the north-west half of the formor curve, and Melfi and the surrounding towns near its south-east end. The principal centre apparently lies midway between Villanova and Lacedonia, but there may have been a secondary centre close to Melfi about 20 miles to the east-south-east. The shock was strong enough to damage a few houses in Naples and to have boon felt in the province of the Marches, and even so far as Rome, so that the total area disturbed may contain about 95,000 square miles, or roughly that of the Hereford earthquake of 1896 . The first movements were recorded at Kew at $0 \mathrm{~h} .12 \mathrm{~m} .11 \mathrm{~s}$. and at Helwan (Egypt) at 0 h. $12 \mathrm{~m} .42 \mathrm{~s}$.

The province of the Basilicata is one of the most unstable regions in Italy. The great Neapolitan earthquake of Doc. 16, 1857, so admirably investigated by Robert Mallet, disturbed chiefly the southern part of the province. Mallet, from observations on the direction of the shock, placed the epicentre near the village of Caggiano, which lies about 34 miles to the south of that of the recent earthquake, but the principal centre was probably near Montomurro, 24 miles south-east of Caggiano. More closoly connected with the recent earthquake are the Avollino earthquake of Sept. 8, 1694, and the Melfi earthquake of Aug. 14, 1851, described by Dr. Mario Baratta in his valuable work "I terremoti d' Italia" (pp. 173$181,407-410 ; 1901)$. In 1694 , the number of persons killed was 3571 . The area of destruction was of unusual size, extending about 50 miles north-west from Potenza. In 1851,628 persons lost their lives, and the moizoseismal area was small, not more than 11 miles in length, with its centre close to Molfi. The area strongly shaken by the recent earthquake thus includes that of the Melfi earthquake and lies along the northern boundary of that of the earthquake of 1694 .

C. Davison.

\section{The Skull of Peking Man.}

$\mathrm{D}$ R. DAVIDSON BLACK'S interim report on the skull of Sinanthropus found at Chou Kou 'Tien at the end of last year was presented at a sossion of the annual mooting of the Geological Society of China held on Mar. 29 last, and has now been published in the Bulletin of the Society. It is illustrated by six plates which reproduce the natural size of the photographs of the frontal, right and left laterals, occipital, vertical and basal views of tho skull.

The whole external surface has now been freed from travertine, with which, however, the interior is still filled. During the preparation of the skull, the major parts of parietals and the whole of the frontal bone were separated from the stone filling; but these wore replaced for the purpose of the photographs, which show the parts in approximately correct relation. A table of measurements is given which supploments and corrects those of the previous report, but they are themselves only approximate and subject to correction.

The skull, doubtfully idontified as fernale, has a glabello-occipital length of $192 \mathrm{~mm}$. and a breadth of $132 \mathrm{~mm}$. (?), the maximum breadth which falls between the supra-mastoid regions of the tomporal bones being circa $144 \mathrm{~mm}$. The loast frontal broadth is $83 \mathrm{~mm}$. (?) and the groatest frontal breadth $102 \mathrm{~mm}$. (?). The auricular height is $97 \mathrm{~mm}$. (?) The parietal eminences are quite well devoloped; but the sides of the cranial vault below them are markedly inclined toward one another. The bones are much thicker in certain regions than was supposed (for example, below the lambda). They do not show the excessive thicknoss of the Piltdown skull, but they are much thicker than in modern man.

One of the most, if not the most interesting point brought out by Dr. Black in this interim report is the bearing of certain unique morphological features which were not apparent at the carlier stages of preparation. It is now clear that what was previously considered to be a markedly developed post-glenoid process is seen to be a very poculiarly developed tympanic portion of the temporal. In the massive parts of the tympanic elements, the posterior moiety is developed to form a prominent crest which extends inward to the base of the minute styloid process, while the anterior portion of the tympanic bone forms a massive rounded wall limiting the mandibular fossa and rising abruptly immediately behind the petro-tympanic fissure. The glenoid cavities are thus obliquely placed deep fossæ, the visible floors of which are formed wholly from the zygomatic elements of the temporal bones. The mandibular fossw are thus wholly hominid in character.

It is, however, extremely interesting to. note that for the first time among hominids is found a stage of development much more archaic than in Neanderthal man and at the same time in certain features recalling some of the relations characterising this region in anthropoids, such, for example, as the chimpanzee. Dr. Black recalls that both Boule and Martin in referenco to the La Chapelle and La Quina skulls respectively have pointed to certain resemblances to the chimpanzee in that region, placing them somewhat intermediately in type between that form and Homo. The Peking skull in this respoct may be termed pre-Noanderthaloid, and in the hominid scale may be not far removed from the type which evolved both the extinct Neanderthal and the modern Homo sapiens.

\section{University and Educational Intelligence.}

LEEDs.-The Council of the University of Loeds has elected Dr. F. Challenger to the chair of organic chemistry shortly to be vacated by Prof. C. K. Ingold. Dr. Challenger, who is at present senior lecturer in chemistry at the University of Manchester, is a graduate of London and Göttingon. Throughout his career he has been actively engaged on research work; amongst the subjects to which he has given attention are the organo-derivatives of bismuth, the organic chemistry of sulphur and the technology of mineral oils, the production of acids such as eitric and oxalic by biological processes, and the chemistry of petroloum.

Manchester.-Applications are invited for the Amy Honrietta Worswick followship for the investigation of the causes and treatment of rheumatoid 
arthritis. The annual value of the fellowship is $£ 150$. The tenure will be for one year with the possible renewal for a second year. Applications must reach the registrar by, at latest, Oct. 15.

In scho is in the United States of Amorica are onrolled more than half of the total population of ages $15,16,17$, and 18 years. 'Twenty-five years ago the proportion was only one-tenth. Some account of this remarkable growth is given, with voluminous statistics of public high schools in 1927-28, in Bulletin, 1929 , No. 35, of the United States Office of Education. The rapid addition of large groups of pupils of types very different from those with which the traditional high school had been accustomed to deal necessitated radical changes, including an expansion of curricula from a strictly limited group of subjects (English, Latin, Greek, French, German, algebra, geometry, physies, chemistry, and general history) to very varied assortments of some two hundred and fifty subjects, of which many are definitely vocational and industrial in character. Other notable changes accompanied the 'junior high school' movement, started about the beginning of the present century. This has led to reorganisations, affecting nearly half of the total public high school enrolment, the main foatures of which are the differential treatment of the age group 16, 17, and 18 years (senior high school) and the absorption in junior high schools or departments of pupils of the higher grades (ages 13-14 years) of the primary schools. The place of sciences in the high schools seems to be a diminishing one, excopt as regards biology, hygiene, and sanitation. In 1910, eighty-two per cent of pupils were studying somo science, in 1915 sixty-four per cent, in 1928 sixty-one per cont. The drop in numbers studying physies, from fifteen to soven per cent, is specially noticeable. Physieal geography and physiology also show important decreases, and geology has almost disappoared from the high school programmes.

Froy the University of Leeds wo have received two roports on its Clothworkers' Departments. 'Thoy are of more than ordinary interest by reason of the highly important developments of research resulting from a special grant of $£ 3000$ by the Clothworkers' Company. A report on these developments describes in some detail researches conductod (i) under the direction of Mr. J. B. Speakman in the plasticity of wool, influence of plastic flow on the affinity of wool for water (already reported in NATURE of Sept. 14, 1929 ), rigidity of wool and its change with adsorption of wator vapour, elastic properties of wool in water at high temperatures, examination of the fine structure of wool by X-ray analysis, thermal conductivity of and transmission of water vapour through textiles, and physico-chemical properties of wool fat; (ii) under Mr. W. T. Astbury's direction, somo applying new X-ray methods of investigation inaugurated by Sir William Bragg to the problems of fibres in general and of wool and hair in particular, and others aiming at the solution of definite technological problems relating to the uniformity of yarns, the significanco of fibre lengths, etc. In the Department of ColourChemistry and Dyeing, the progressive decline which has characterised enrolments of the past docade was followed last year by a considerable increase and the demand by industry for graduate students trained in the Department exceeded the supply availablo. Huddersfield Technical College also reports heavy enrolments in its dyeing department and an important growth of research work in all its departments, especially in colour chemistry and chemistry, and almost complete success by its appointment department in placing students in suitable positions.

\section{Historic Natural Events.}

Aug. 3, x879. Hailstorm near London.-- Over an area seven miles long and two miles broad, between Kingston and Faling, violent hail fell. The stones were up to six inches in circumference, broke all glass exposed to them, pierced holes in zinc and slate roofs, and knocked out of shape the anemometer cups at Kow Observatory. The thunder and lightning were continuous from 9 P.M. to 3 A.M. ; at Cambridge at 3 A.M. thero were 120 flashes per minute.

Aug. 3, I883. Cloudburst on Ochil Hills.-During the afternoon a violent storm burst on the Ochil Hills betweon Dollar and Alva. A flood of water poured down a deep narrow valley into Alva, the main street becoming deeply flooded in three minutes. Bags of flour and casks of butter were floated a distance of 100 yards from a baker's shop.

Aug. 4, I577. Damage by Lightning in Suffolk.On Sunday, Aug. 4, between 9 and 10 A.M., the parish church of Blythburgh, in Suffolk, was struck by light. ning, which burst through the wall, struck almost a yard doop into the ground, and knocked down about twenty people who were on that side of the church. It then broke the door and badly damaged the steeple, breaking the timber and the bells. The people that wore stricken down were found still grovelling more than half an hour afterwards, and two were dead. About the same time the parish ehurch of Bungay, nine miles from Norwich, was alșo struck, the wire and wheels of the clock being broken and two men in the belfry killed, while in the church itself men were killed or burned.

Aug. 4, r666. Hurricane at Guadeloupe.-A hurricane began at 6 P.M. and continued for twenty-four hours. Fvery vessel and boat on the coast of Guadeloupe was dashed to pieces, all the vessels in the Saints were driven on shore, and of Lord Willoughby's fleet of 17 sail with 2000 troops, only two were over heard of afterwards. Houses and trees were blown down and a great number of cattle killed. The sea rose to an unusual height and flooded the land.

Aug. 4, I829. Moray Floods.-Heavy rain began to fall on the evening of Aug. 2 in the upper parts of the valleys of the rivers Nairn, Findhorn and Spey, and continued almost without interruption until the morning of Aug. 4. It came mainly with a north-east wind, with such volume and force that it ponetrated all the doors and windows facing in that direction. No rain-gauges were in operation in the area of heaviest fall, but it is not unlikely that the amount which fell on Aug. 3 exceeded any falls which have boen actually recorded in the British Isles. The Findhorn at its greatest height fillod the valley, 200 yards wide, to a depth of 17 feet above the normal surface of the river, this lovel being marked by a tablet.

Aug. 5, I783. Great Eruption of the Asama-yama (Japan). - The Asama-yama, one of the principal Japanese volcanoes, lies 90 miles north-west of Tokyo and rises to a height of 8136 feet above the sea. The great eruption of 1783 began on May 9 and lasted 88 days, culminating on Aug. 5, when a huge mass of molten lava and hot mud descended from the crater and covered an area 2 miles from the crater and 4 miles wide at the base to a mean depth of 100 feet. This lava did not reach the villages and caused no loss of life or property. It was followed, however, by a great avalanche of volcanic materials that swept down, at first with a velocity of more than 50 miles an hour, and caused enormous damage in all the villages along the northern base of the mountain. The river Azuma-gawa was blocked for a time, but the gathering waters broke through the dam and

No. 3170, VoL. 126] 